\title{
Evaluation of Pretreatment Serum Albumin-to-Globulin Ratio in Dogs with Naturally Occurring Parvovirus Infection ${ }^{[*]}$
}

\author{
Didem PEKMEZCI'1* Kübra ÇAKIR ${ }^{2}$ \\ ${ }^{1}$ Department of Internal Medicine, Faculty of Veterinary Medicine, University of Ondokuz Mayis, 55200 Kurupelit, Samsun, Turkey. \\ ${ }^{2}$ Masal Veterinary Clinic, Yahyakaptan, Kocaeli, Turkey.
}

How to cite: Pekmezci, D. \& Çakır, K. (2020). Evaluation of Pretreatment Serum Albumin-to-Globulin Ratio in Dogs with Naturally Occurring Parvovirus Infection. J. Anatolian Env. and Anim. Sciences, 5(2), 118-124.

Atıf yapmak için: Pekmezci, D. \& Çakır, K. (2020). Doğal Parvovirus ile Enfekte Köpeklerde Tedavi Öncesi Serum Albuminin Globuline Oranının Değerlendirilmesi. Anadolu Çev. ve Hay. Dergisi, 5(2), 118-124.

: https://orcid.org/0000-0003-2072-8165 (iD): https://orcid.org/0000-0001-7488-1400

*Corresponding author's: Didem PEKMEZCI

Department of Internal Medicine, Faculty of Veterinary Medicine, University of Ondokuz Mayis, 55200 Kurupelit, Samsun, Turkey

\:dkazanci@omu.edu.tr

Mobile telephone : +90 (505) 4779524

Telephone $\quad:+90(362) 3121919$

Fax : +90(362) 4576922
Abstract: A pretreatment albumin (ALB)-to-globulin (GLB) ratio (AGR) with a predictive significance has been used as an indispensable marker among cancer types for recurrence and prognosis in human patients. This study aims to determine whether the pretreatment AGR and total calcium ( $\mathrm{tCa})$, magnesium $(\mathrm{Mg})$, ionised phosphorus (iP), total protein (TP), and haematology parameters as bedside markers differs in dogs with naturally occurring parvovirus infection (PVI). Fourteen client-owned dogs aged 2-8 months that were naturally infected with parvovirus (PV) were enrolled as the study group. Seven client-owned, healthy dogs of the same age formed the control group. Pretreatment mean complete blood counts, serum tCa, Mg, iP, TP, ALB, globulin GLB and AGR values, were compared between groups. The pretreatment mean WBC, NEU, LYM, EOS, GLB, and TP levels were found to be significantly lower $(\mathrm{P}<0.05)$ in the study group, when compared to the control group. On the other hand, pretreatment AGR with iP was found to be statistically higher $(\mathrm{P}<0.05)$ in the study group, when compared to the control group. There was a significant positive correlation between mean serum GLB and WBC levels in the current study. A significant positive correlation between mean serum TP and WBC levels was also found. This preliminary study demonstrates that pretreatment serum GLB levels and the AGR as easy, inexpensive, objective, and non-invasive biomarkers could be the new prognostic marker candidates in dogs with naturally occurring PVI.

$\underline{\text { Keywords: Albumin-to-globulin ratio, canine, globulin, parvovirus, prognostic marker candidate. }}$

\section{Doğal Parvovirus ile Enfekte Köpeklerde Tedavi Öncesi Serum Albuminin Globuline Oranının Değerlendirilmesi}

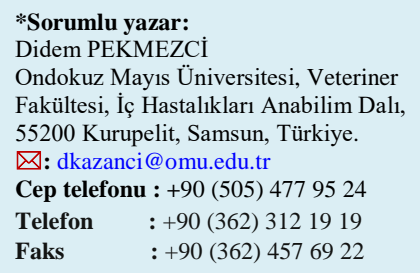

Öz: Tedavi öncesi albüminin (ALB) globüline (GLB) oranı (AGO) çeşitli kanser vakalarının nüks ve prognozunun değerlendirilmesinde prediktif öneme sahip ve vazgeçilmez bir belirteçtir. Mevcut çalışmanın amacı ise tedavi öncesi başucu belirteçlerinden AGO ile total kalsiyum (tCa), magnezyum (Mg), iyonize fosfor (iP), total protein (TP) ve hematolojik belirteçlerin doğal olarak parvovirus enfeksiyonu (PVE) şekillenen köpeklerde değişip değişmediğinin belirlenmesidir. On dört adet yaşları 2 ila 8 aylık arasında değişen, doğal parvovirus (PV) ile enfekte köpek çalışma grubunu oluşturmuştur. Yedi adet, aynı yaş aralığında sağlıklı ve sahipli köpek ise kontrol grubunu oluşturmuştur. Tedavi öncesi ortalama total kan sayımı, serum tCa, Mg, iP, TP, ALB, GLB ve AGO değerleri gruplar arasında karşılaştırılmıştır. Tedavi öncesi kontrol grubu WBC, NEU, LYM, EOS, GLB ve TP seviyelerinin kontrol grubuna göre istatiksel $(P<0.05)$ olarak düşük olduğu tespit edilmiştir. Diğer taraftan çalışma grubunun tedavi öncesi AGO ile iP değerleri kontrol grubuna göre istatiksel olarak $(\mathrm{P}<0.05)$ yüksek bulunmuştur. Serum GLB ile WBC değerleri arasında ise mevcut çalı̧̧mada pozitif bir korelasyon bulunmuştur. TP ile WBC değerleri arasında ise güçlü bir korelasyon tespit edilmiştir. Bu öncü çalışma ile tedavi öncesi GLB ile AGO değerlerinin, maliyetsiz, objektif ve non-invazif biyobelirteçler olarak doğal PVE şekillenen köpeklerde yeni prognostik belirteç adayları olabileceği ortaya konulmuştur.

Anahtar kelimeler: Albuminin globuline oranı, globulin, kanin, parvovirus, prognostik belirtec aday1. 


\section{INTRODUCTION}

Parvovirus (PV), which first emerged in the mid1970s, is an important infectious disease with high morbidity and mortality, especially in dogs younger than 6 months, and has remained as a major enteric pathogen worldwide (Appel et al., 1978; McCaw et al., 2006). The characteristic signs of parvovirus infection (PVI) in dogs include haemorrhagic diarrhoea, vomiting, loss of appetite, lethargy, fever, severe dehydration, sudden collapse, and death (Goddard \& Leisewitz, 2010; Yilmaz \& Senturk, 2007). There are factors, including the host, pathogen, secondary infections, underlying stressors and environment that affect the severity and outcome of PVI in dogs. However, it has been reported that the chances of death are higher in PV-infected dogs who have evidence of systemic inflammation at the time of admission, compared with those who do not (Kalli et al., 2010). Numerous clinicopathologic biomarkers, including haematology (Goddard et al., 2008), coagulation (Otto et al., 2000) and serum biochemistry (Kalli et al., 2010; McClure et al., 2013; Yilmaz \& Senturk, 2007) have been introduced as prognosticators in dogs naturally infected with PV, especially for predicting survival and duration of hospitalisation. The availability of several predictors may help the clinician identify patients at a high risk of death and assist in decision making when discussing treatment options or euthanasia with clients (Schoeman et al., 2013).

The determination of the serum total protein (TP) level is a main assessment tool in general biochemistry and is routine in daily clinical veterinary practice (Tothova et al., 2016). The assessment of serum protein differences over the duration of a disease is fundamental for their use as valid biomarkers (Okutucu et al., 2007). Serum proteins can be separated into four main fractions - albumin (ALB), $\alpha$-, $\beta$-, and $\gamma$-globulins - based on their electrophoresis (Bossuyt, 2006); these fractions display significant differences in domestic animals. ALB, $\alpha_{1^{-}}, \alpha_{2^{-}}, \beta_{1^{-}}, \beta_{2^{-}}$, and $\gamma$-globulins are the determined fractions in healthy dogs (Abate et al., 2000). ALB and globulin (GLB) represent the two major reflector constituents of serum proteins that have roles in systemic inflammation in animals (Kaneko, 1997). ALB is the most important-negative acute-phase protein found in serum and constitutes $35-50 \%$ of the TP (Kaneko, 1997). Increased serum GLB levels may show a chronic inflammatory response and cumulative exposure to different inflammatory cytokines (Sugimoto et al., 2012). Alterations in serum GLB levels are associated with changes in its fractions, and alterations in the concentration of ALB and GLD lead to changes in the albumin-toglobulin ratio (AGR), which provides a systematic approach to the interpretation of protein dyscrasias (Eckersall et al., 2008).
Therefore, determination of serum TP panels with individual fractions provides an excellent basis for probable diagnosis and for additional examination of the patient (Eckersall et al., 2008). Recently, pretreatment AGR with a prognostic significance has been used as an indispensable marker among various cancer types for recurrence and prognosis in human patients (Chen et al., 2017; He et al., 2017; Lin et al., 2017). A higher AGR reflects the underproduction of globulins and provides significant information about the alterations in the electrophoretic pattern with classifying disruption of protein fractions (Alberghina et al., 2011). AGR measurement is inexpensive, easy to test for, and a standardised evaluation criterion in numerous diseases worldwide (Zhou et al., 2016). None of the common bedside blood serum biochemistry panels have yet been able to predict survival, outcome, or DOH in dogs naturally infected with PV (Mann et al., 1998).

However, the acute response of pretreatment GLB levels and the AGR in dogs naturally infected with PV has not yet been investigated. Thus, the determination of GLB levels and the AGR may provide important prognostic value for dogs naturally infected with PV. Therefore, our primary interest in the current study is to determine whether pretreatment serum GLB levels and the AGR, as bedside markers, differ in dogs naturally infected with PV from healthy dogs.

\section{MATERIAL AND METHOD}

Research Material: Twenty-one client-owned dogs, 2-8 months of age, of any breed and either sex, brought to the Veterinary Teaching Hospital from April 2017-May 2018 were enrolled in the current study. Fourteen dogs naturally infected with PV-diagnosed based on the positive result of a rapid detection kit (ASAN Easy Test ${ }^{\circledR}$ ) for PV antigens in faeces-were placed in the study group. None of the 7 healthy dogs had any clinical sign of PVI, or other diseases, prior to the sampling. The healthy dogs had been brought into the clinic by clients for general examinations and routine blood checks. The healthy dogs formed the control group. Data from the complete blood count of the dogs including signalment, result of rapid detection kit for PVI obtained from the medical records. This study was approved by the Local Ethical Committee for Animal Studies (certificate no. 2016/64). The dogs naturally infected with PV were treated according to a standard protocol reported by Hoskins (1998).

Procedures: Venous blood was taken from the cephalic vein of each dog in the study at the time of admission to the Veterinary Teaching Hospital, with $2 \mathrm{ml}$ 
evacuated into a plain additive tube with K3 EDTA (7.5\% $0.040 \mathrm{ml}$ ) and $5 \mathrm{ml}$ into a vacutainer without anticoagulant, for biochemical analysis. The $5 \mathrm{ml}$ sample was centrifuged at $3000 \mathrm{~g}$ for 10 minutes at room temperature. Serum samples were separated and stored at $-80^{\circ} \mathrm{C}$ until analysis. Complete blood count analysis was performed by a BC5000 Vet Auto Haematology Analyzer Mindray ${ }^{\circledR}$, and results were recorded. Serum tCa, Mg, iP, ALB, and TP values were measured using a BS 120 Chemistry Analyzer Mindray ${ }^{\circledR}$. GLB was calculated using the equation GLB = TP - ALB. The AGR was calculated using the equation $\mathrm{AGR}=\mathrm{ALB} / \mathrm{GLB}$.

Statistical Analysis: The complete blood count (NEU, LYM, MONO, EOS, BAS, NEU\%, LY\%, $\mathrm{MONO} \%, \mathrm{EOS} \%$, BAS\%, RBC, HGB, HCT, MCV, MCH, MCHC, RDW-CV, RDW-SD, PLT, PCT, MPV, and PDW); serum tCa, Mg, iP, ALB, GLB, and TP; and the AGR were the analysed parameters. The resulting datasets were analysed for normality using the Shapiro-Wilk test. The Student-t test was used for the parameters that showed normality. The Mann-Whitney $U$ test was used for the variables that did not show normality. Pearson's correlation coefficients were calculated to determine whether serum TP and GLB concentrations and the AGR were linearly associated with WBC and LYM values. All comparisons were considered statistically significant when $\mathrm{P}<0.05$.

\section{RESULTS AND DISCUSSION}

The mean WBC of the study group $\left(7.569 \times 10^{9} /\right.$ L) was found to be statistically $(P=0.000)$ lower than the mean WBC of the control group $\left(15.636 \times 10^{9} / \mathrm{L}\right)$. There were significant differences $(\mathrm{P}=0.000)$ found in the mean NEU and LYM $(P=0.013)$ levels of the study group versus the control group (Figure 1). On the other hand, mean MON, EOS, BAS, MONO\%, MCV, and MCH levels not showed normality. The Mann-Whitney $U$ test performed to the mean MON, EOS, BAS, MONO\%, MCV, and $\mathrm{MCH}$ levels. Only the mean EOS level in the study group was found to be statistically significant $(\mathrm{P}=0.006)$, when compared to the control group (Figure 1).

Of the serum biochemistry variables, only the serum iP level showed normality. Same as the MannWhitney $U$ test performed for analysing mean serum iP levels. The mean serum iP level in the study group was also found to be statistically higher $(\mathrm{P}=0.044)$, when compared to the control group (Figure 2).

Mean serum GLB $(P=0.001)$ and TP $(P=0.003)$ levels were found to be statistically lower than control levels (Figure 3). The mean serum AGR in the study group (0.64) was found to be statistically higher $(\mathrm{P}=0.012)$ than the control mean serum AGR (0.50) (Figure 3).
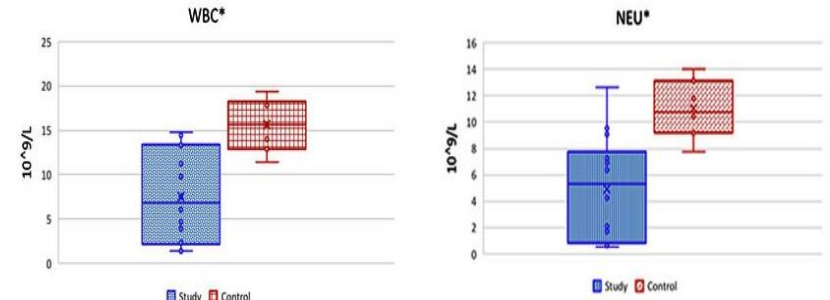

LYM* $^{*}$
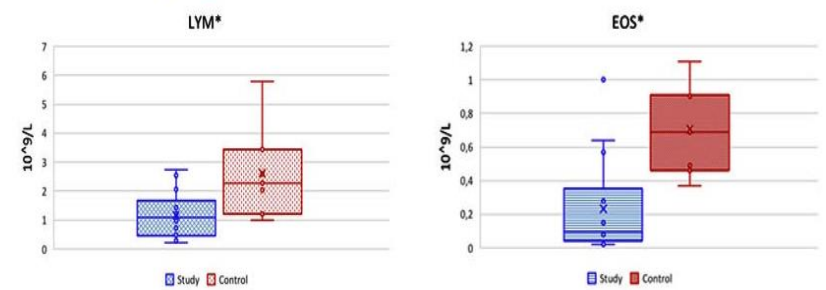

Figure 1. Box-and-whiskers plot of pretreatment WBC, NEU, LYM, and EOS values in dogs with infected PV (blue boxes) or healthy controls (red boxes). The box incorporates the middle $50 \%$ of observation; the bottom of the box is the first quartile $\left(25^{\text {th }}\right.$ percentile) and the top of the box is the third quartile $\left(75^{\text {th }}\right.$ percentile). The horizontal line in the middle of the box is the median $\left(50^{\text {th }}\right.$ percentile). The cross within each box represents the mean value. The whiskers extend to the smallest and largest observations that are 1.5 times removed from the interquartile range are plotted separately as dots.

*Significant difference between dogs with study and control group, $\mathrm{P}<0.05$.

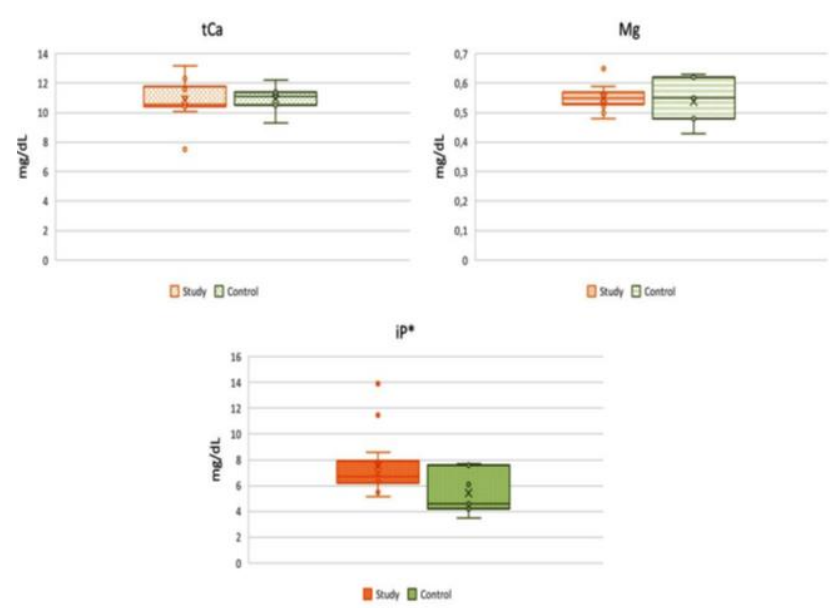

Figure 2. Box-and-whiskers plot of pretreatment serum $\mathrm{tCa}, \mathrm{Mg}$, and iP levels in dogs with infected PV (orange boxes) or healthy controls (green boxes). The box incorporates the middle $50 \%$ of observation; the bottom of the box is the first quartile $\left(25^{\text {th }}\right.$ percentile) and the top of the box is the third quartile $\left(75^{\text {th }}\right.$ percentile). The horizontal line in the middle of the box is the median (50th percentile). The cross within each box represents the mean value. The whiskers extend to the smallest and largest observations that are 1.5 times removed from the interquartile range are plotted separately as dots.

*Significant difference between dogs with study and control group, $\mathrm{P}<0.05$. 

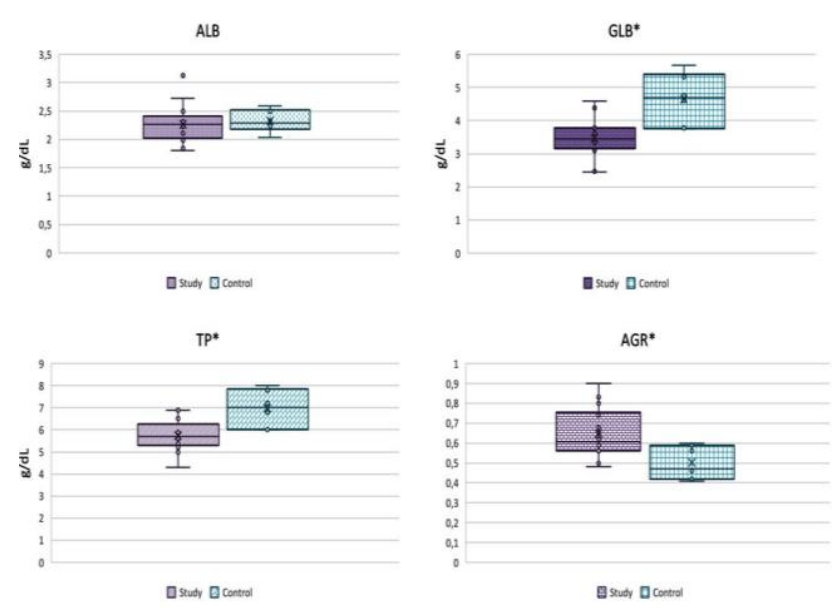

Figure 3. Box-and-whiskers plot of pretreatment serum ALB, GLB, TP and AGR values in dogs with infected PV (purple boxes) or healthy controls (turquoise boxes). The box incorporates the middle $50 \%$ of observation; the bottom of the box is the first quartile ( $25^{\text {th }}$ percentile) and the top of the box is the third quartile $\left(75^{\text {th }}\right.$ percentile). The horizontal line in the middle of the box is the median $\left(50^{\text {th }}\right.$ percentile). The cross within each box represents the mean value. The whiskers extend to the smallest and largest observations that are 1.5 times removed from the interquartile range are plotted separately as dots.

* Significant difference between dogs with study and control group, $\mathrm{P}<0.05$.

In addition, a positive significant correlation $(\mathrm{P}<$ 0.05 ) between serum TP and WBC was found (Table 1). A positive significant correlation $(\mathrm{P}<0.05)$ was also found between serum GLB and WBC levels (Table 1).

Table 1. Pearson correlations of mean TP, GLB, AGR, WBC, and LYM values.

\begin{tabular}{|c|c|c|c|c|c|c|}
\hline & & TP & GLB & AGR & WBC & LYM \\
\hline \multirow{3}{*}{ TP } & Pearson Correlation & 1 & $.951^{* *}$ & $-.616^{* *}$ & $.554^{* *}$ & .303 \\
\hline & Sig. (2-tailed) & & .000 & .003 & .009 & .181 \\
\hline & $\mathrm{N}$ & 21 & 21 & 21 & 21 & 21 \\
\hline \multirow{3}{*}{ GLB } & Pearson Correlation & $.951^{* *}$ & 1 & $-.822^{* *}$ & $.463^{*}$ & .213 \\
\hline & Sig. (2-tailed) & .000 & & .000 & .035 & .354 \\
\hline & $\mathrm{N}$ & 21 & 21 & 21 & 21 & 21 \\
\hline \multirow{3}{*}{ AGR } & Pearson Correlation & $-.616^{* *}$ & $-.822^{* *}$ & 1 & -.184 & -.026 \\
\hline & Sig. (2-tailed) & .003 & .000 & & .424 & .910 \\
\hline & $\mathrm{N}$ & 21 & 21 & 21 & 21 & 21 \\
\hline \multirow{3}{*}{ WBC } & Pearson Correlation & $.554^{* *}$ & $.463^{*}$ & -.184 & 1 & $.675^{* *}$ \\
\hline & Sig. (2-tailed) & .009 & .035 & .424 & & .001 \\
\hline & $\mathrm{N}$ & 21 & 21 & 21 & 21 & 21 \\
\hline \multirow{3}{*}{ LYM } & Pearson Correlation & .303 & .213 & -.026 & $.675^{* *}$ & 1 \\
\hline & Sig. (2-tailed) & .181 & .354 & .910 & .001 & \\
\hline & $\mathrm{N}$ & 21 & 21 & 21 & 21 & 21 \\
\hline
\end{tabular}

*Correlation is significant at the 0.05 level (2-tailed).

A WBC count below $4.5 \times 10^{9} / \mathrm{L}$ indicates a poor prognosis and the need for aggressive treatment in dogs with PVI (Castro et al., 2013). A significantly transient lymphopenia is frequently characterised in dogs with PVI results in a decrease in the leucocyte number (Ling et al., 2012). Destruction of the haematopoietic progenitor cells leads to this leucopoenia, which is usually proportional to the severity and stage of the disease (Hoskins, 2001). Neutrophils are the most numerous types of leukocytes in dogs' blood and provide the first line of defence against invading microorganisms, tissue trauma, or any inciting inflammatory signal. Severe neutropenia is also seen in dogs with
PVI resulting the destruction of myeloblasts in bone marrow with a massive loss of neutrophils from the intestinal wall (Rørtveit et al., 2011). Lymphopenia is an important finding that reflects suppressed humoral and cell-mediated immune responses in dogs with PVI. Goddard et al. (2008) report that lymphopenia in PVIinfected puppies in their research might have occurred as a direct effect of the virus, leading to atrophy or destruction of lymphoid tissues or the releasing of high amounts of cortisol. In the study reported here, only the mean WBC, NEU, LYM, and EOS values of the study group were seen to be statistically decreased versus the control group of dogs. All mean WBC, NEU, LYM, and EOS parameters for the dogs enrolled in the study were under the reference ranges for puppies aged 28-60 days (Rørtveit et al., 2011). Our results were consistent with those previously reported for the decreasing mean WBC, NEU, LYM, and EOS values expected in dogs naturally infected with PVI (Goddard et al., 2008; Ling et al., 2012).

Changes in serum biochemistry related to infections are believed to be nonspecific (Schoeman et al., 2013). Research determining mean serum $\mathrm{tCa}, \mathrm{Mg}$, and iP levels are limited of the studies investigating serum biochemistry changes in dogs with PVI. Jacobs et al. (1980) emphasised that total blood Ca concentrations may be diminished due to hypoalbuminemia in dogs with PVI. Jacobs et al. (1980) also advocated that increased blood urea, creatinine, and inorganic phosphate are all associated with dehydration. Contrary to the findings of Jacobs et al. (1980) our results showed the mean $\mathrm{tCa}$ levels of the dogs infected with PV were not decreased. There was no statistical significance found in the mean serum tCa concentrations between the study and control groups in the present study. Even though up to $60 \%$ of all critically ill human patients are found to be $\mathrm{Mg}$-deficient (Escuela et al., 2005). Mann et al. (1998) reported that total and ionised $\mathrm{Mg}$ concentrations were not significantly different between healthy dogs and dogs with PVI or between dogs surviving and those not surviving PVI. Our results are consistent with those of Mann et al. (1998); the serum Mg levels in the study group were not different from the healthy controls. In accordance with the results of Jacobs et al. (1980), serum iP levels in the current study were found to be statistically higher in the study group than in the control group.

Abnormal serum protein profiles provide significant diagnostic assistance in clinical practice, though a definitive diagnosis can seldom be made with their determinations (Eckersall et al., 2008). Hypoproteinaemia with hypoglycaemia was found to be related to poor survival in dogs with PVI (Castro et al., 2013). Same as our results for mean serum TP in the study group showed a statistically important decrease comparing to the control value. Protein-losing enteropathy, intestinal haemorrhage, SIRS-mediated vascular permeability, and subsequent rehydration therapy are the accepted factors affecting plasma proteins throughout the course of PVI in dogs (Mazzaferro et al., 2002; Van den Broek, 1990). Decreased serum ALB levels indicate poor nutritional status and poor survival for different types of cancers, including lung, nasopharyngeal, breast, and laryngeal cancers in humans (Chen et al., 2017; He et al., 2017; Lin et al., 2017). Low serum ALB concentrations in dogs infected with PV Castro et al. (2013) was found to increase DOH (Kalli et al., 2010). Contrary to the low serum ALB concentrations in dogs with PVI found in previously published research, our results demonstrated that mean serum ALB levels did not differ among the study and control groups (Castro et al., 2013; Kalli et al., 2010). Our mean serum ALB levels in both groups were found to be in the reference ranges for dogs aged 60 days (Rørtveit et al., 2011). Aforementioned globulins in healthy dogs in the serum reflect particular health conditions. Despite the determination of various biochemical parameters, including APPs, in naturally PV infected dogs; information about serum GLB levels, and their fractions, in dogs infected with PV is very limited. Van den Broek 
(1990) found a significant decrease in the mean level of $\gamma$ globulins, and increased $\alpha_{2}$-globulins, in dogs with confirmed PVI by determining the agarose gel electrophoresis before treatment. An important study that investigated serum protein electrophoresis in dogs with PVI demonstrated that there are relative and absolute hypoalbuminemia, hypo- $\gamma$-globulinemia, and hyper- $\alpha_{2}$-globulinemia (Van den Broek, 1990). Recently, Castro et al. (2013) showed that dogs with PVI also had hypoglobulinemia. In accordance with those published results, the mean GLB level in our study group was found to be statistically lower than in the control group.

The $\alpha$ and $\beta$ GLB fractions include APPs, such as haptoglobin, ceruloplasmin, C3 complement, C4 complement, Creactive protein (CRP), and fibrinogen (Shibutani et al., 2015) Recently, studies conducted on the determination of APPs, especially CRP, in dogs naturally infected with PV show that the concentration of this APP increases over the course of the disease and may be used as a prognostic indicator (McClure $\mathrm{V}$ et al., 2013). However, these researchers did not give information about the mean serum GLB levels in PV-infected dogs with high levels of CRP (McClure V et al., 2013). At first sight, there seems to be a parallel between increasing levels of CRP and low GLB concentrations. Therefore, agarose gel electrophoresis should be performed to indicate which fractions of these globulins are altered.

Van den Broek (1990) found hyper- $\alpha_{2}$-globulinemia in dogs with PVI; this GLB fraction reflects the amount of APPs. Van den Broek (1990) also found that, in addition to hyper- $\alpha_{2}-$ globulinemia, there was also hypo- $\gamma$-globulinemia in dogs with PVI. While hypo- $\gamma$-globulinemia and this pattern are typical for foetal or pre-colostral sera in some animal species, it may also be seen in patients with recurrent infections or in cases of immune deficiency (Weaver et al., 2000). Occurrence of hypo- $\gamma$ globulinemia in dogs naturally infected with PV may be associated with the lack of passive immunisation.

Changes in the concentrations of ALB and GLB also lead to shifts in the AGR. Normal AGR in dogs and cats presents as 0.6-1.1 (Krimer, 2011). Rørtveit et al. (2011) also found AGRs of 1.0-1.2 in puppies aged 16-60 days. However, our resultseven in the healthy controls - were all lower than those reported by Rørtveit et al. (2011). The main explanation of our different AGRs in healthy dogs may be attributed to analytical methods (Rørtveit et al., 2011). Rørtveit et al. (2011) used different analytical methods for measuring serum ALB and TP in that study. Our ALB and TP results were all obtained using a chemistry analyser, and the GLB levels were calculated using the equation GLB=TP-ALB. In addition, various disease conditions may alter the relative amounts of ALB and GLB and lead to changes in their proportions (Kaneko, 1997). Therefore, the significant decrease in mean GLB levels in the dogs infected with PV in the present study-with no alteration in mean ALB levels - led to a significant increase in the AGR, compared to the control values in our study. Meanwhile, a significant positive correlation between serum GLB and WBC levels was also found in the current study. Same as a significant positive correlation between serum TP and WBC levels were also found.

The availability of prognostic tests does not completely release the practitioner from making clinical decisions (Schoeman et al., 2013), and prognostication remains a challenging topic (McClure et al., 2013). The clinician has to face the stressful situation of deciding which the appropriate test to measure is and what cut-off value would constitute enough evidence to support a decision for euthanasia or continued treatment in a dog with PVI (Schoeman et al., 2013). Though the composite clinical score introduced by Mohr et al. (2003) as an indispensable prognosticating tool in dogs with PVI is still valid, the establishment of new, cost-effective laboratory biomarkers for prognostication of survival, outcome, and $\mathrm{DOH}$ would be useful (Prittie, 2004).

\section{CONCLUSIONS}

The main limitation of the current study was the absence of information about the electrophoretic patterns of the study materials. Mispresenting the DOH with survival rates of dogs with PVI is the other limitation. Furthermore, a more detailed look at the predictive and prognostic values of pretreatment serum GLB levels and the AGR using multivariate analysis in the form of logistic regression or Cox proportional hazard analysis needs to be demonstrated with future studies about this highly contagious disease.

In summary, this preliminary study demonstrates that pretreatment serum GLB levels and the AGR are easy, costeffective, objective, and non-invasive biomarkers that could be the new prognostic marker candidates in dogs naturally infected with PV.

\section{ACKNOWLEDGEMENTS}

The authors are especially thankful to Murat Bayazit and Merve Parmaksiz from Istar Consultancy, Turkey for performing the statistical analyses of this study.

\section{CONFLICT OF INTEREST}

The authors declare that they have no competing interests.

\section{REFERENCES}

Abate, O., Zanatta, R., Malisano, T. \& Dotta, U. (2000). Canine serum protein patterns using highresolution electrophoresis (HRE). The Veterinary Journal, 159, 150-154.

Alberghina, D., Giannetto, C., Vazzana, I., Ferrantelli, V. \& Piccione, G. (2011). Reference intervals for total protein concentration, serum protein fractions, and albumin/globulin ratios in clinically healthy dairy cows. Journal of Veterinary Diagnostic Investigation, 23, 111-114.

Appel, M.J.G., Cooper, B.J., Greisen, H. \& Carmicheal, L.E. (1978). Status report: canine viral enteritis. Journal of the American Veterinary Medical Association, 173, 1516-1518.

Bossuyt, X. (2006). Advances in serum protein electrophoresis. Advances in Clinical Chemistry, 42, 43-80.

Castro, T.X., Rita de Cassia, N., Goncalves, L.P., Costa, E.M. \& Marcello, G.C. (2013). Clinical, hematological, and biochemical findings in puppies with coronavirus and parvovirus enteritis. Canadian Veterinary Journal, 54, 885-888.

Chen, W.Z., Yu, S.T., Xie, R., Lv, Y.X., Xu, D.B. \& Yu, J.C. (2017). Preoperative albumin/globulin ratio 
has predictive value for patients with laryngeal squamous cell carcinoma. Oncotarget, 8, 4824048247.

Eckersall, P.D. (2008). Proteins, proteomics, and the dysproteinemias, In: Kaneko, J.J., Harvey, J.W. \& Bruss, M.L. (Ed), Clinical Biochemistry of Domestic Animals. 6th ed., 117-155p, Elsevier Academic Press, California, USA.

Escuela, M.P., Guerra, M., Anon, J.M., MartínezVizcaíno, V., Zapatero, M.D., Jalon, A.G. \& Celeya, S. (2005). Total and ionized serum magnesium in critically ill patients. Intensive Care Medicine, 31, 151-156.

Goddard, A., Leisewitz, A., Christopher, M., Duncan, N.M. \& Becker, P.J. (2008). Prognostic usefulness of blood leukocyte changes in canine parvoviral enteritis. Journal of Veterinary Internal Medicine, 22, 309-316.

Goddard, A. \& Leisewitz, A.L. (2010). Canine parvovirus. Veterinary Clinics of North America: Small Animal Practice, 40, 1041-1053.

He, X., Guo, S., Chen, D., Chen, X., Zhang, Y., He, Q., Quin, Z., Liu, Z., Xue, Y., Zhang, M., Liu, R., Zhou, F., Han, H. \& Yao, K. (2017). Preoperative albumin to globulin ratio (AGR) as prognostic factor in renal cell carcinoma. Journal of Cancer, 8, 258-265.

Hoskins, J.D. (2001). Canine viral enteritis, In: Ettinger, S.J. (Ed), Pocket Companion to Text Book of Veterinary Internal Medicine. 5th ed., 214-218p, WB Saunders Company, Philadelphia, USA.

Hoskins, J.D. (1998). Canine viral enteritis, In: Greene, C.E. (Ed), Infectious Diseases of the Dog and Cat. 2nd ed., 40-45p, WB Saunders Company, Toronto, Ontario, USA

Jacobs, R.M., Weiser, M.G., Hall, R.L. \& Kowalski, J.J. (1980). Clinicopathologic features of canine parvoviral enteritis. Journal of the American Animal Hospital Association, 16, 809-814.

Kalli, I., Leontides, L.S., Mylonakis, M.E., AdamamaMoraitou, K., Rallis, T. \& Kouitinas, A.F. (2010). Factors affecting the occurrence, duration of hospitalization and final outcome in canine parvovirus infection. Research in Veterinary Science, 89, 174-178.

Kaneko, J.J. (1997). Serum proteins and the dysproteinemias, In: Kaneko, J.J. (Ed), Clinical Biochemistry of Domestic Animals. 5th ed, $117-$ 138 , Academic Press, London, UK.

Krimer, P.M. (2011). Generating and interpreting test results: test validity, quality control, reference values, and basic epidemiology, In: Latimer, K.S. (Ed), Duncan and Prasse's Veterinary
Laboratory Medicine: Clinical Pathology. 5th ed., 365-382p, Wiley-Blackwell, Chichester.

Lin, Q., Lin, Z., Chen, J., Lin, J.X., Li, X., Jiang J.R., Ma, X.K., Wu, D.H., Chen, Z.H., Dong, M., Wei, L., Wang, T.T., Ruan, D.Y., Lin, Z.X., Wen, J.Y., Wu, X.Y. \& Huang, M.S. (2017). Prognostic significance of preoperative albuminto-globulin ratio in patients with cholangiocarcinoma. Current Research in Translational Medicine, 65, 83-87.

Ling, M., Norris, J.M., Kelman, M. \& Ward, M.P. (2012). Risk factors for death from canine parvoviral related disease in Australia. Veterinary Microbiology, 158, 280-290.

Mann, F., Boon, G., Wagner-Mann, C., Ruben, D.S. \& Harrington, D.P. (1998). Ionized and total magnesium concentrations in blood from dogs with naturally acquired parvoviral enteritis. Journal of the American Veterinary Medical Association, 212, 1398-1401.

Mazzaferro, E.M., Rudloff, E. \& Kirby, R. (2002). The role of albumin replacement in the critically ill veterinary patient. Journal of Veterinary Emergency and Critical Care, 12, 113-124.

McCaw, D.L. \& Hoskins, J.D. (2006). Canine viral enteritis, In: Greene, C.E. (Ed), Infectious Diseases of the Dog and Cat. 3trd ed., 63-73p, Saunders Elsevier, St. Louis.

McClure, V., Schoor, M., Thompson, P.N., KjelgaardHansen, M. \& Goddard, A. (2013). Evaluation of the use of serum C-reactive protein concentration to predict outcome in puppies infected with canine parvovirus. Journal of the American Veterinary Medical Association, 243, 361-366.

Mohr, A.J., Leisewitz, A.L., Jacobson, L.S., Steiner, J.M., Ruaux, C.G. \& Williams, D.A. (2003). Effect of early enteral nutrition on intestinal permeability, intestinal protein loss, and outcome in dogs with severe parvoviral enteritis. Journal of Veterinary Internal Medicine, 17, 791-798.

Okutucu, B., Dincer, A., Habib, O. \& Zihnioglu, F. (2007). Comparison of five methods for determination of total plasma protein concentration. Journal of Biochemical and Biophysical Methods, 70, 709-711.

Otto, C.M., Rieser, T.M., Brooks, M.B. \& Russell, M.W. (2000). Evidence of hypercoagulability in dogs with parvoviral enteritis. Journal of the American Veterinary Medical Association, 217, 1500-1504. 
Prittie, J. (2004). Canine parvoviral enteritis: a review of diagnosis, management, and prevention. Journal of Veterinary Internal Medicine, 14, 167-176.

Rørtveit, R., Sævik, B.K., Eggertsdottir, A.V., Skancke, E. \& Lingaas, F. (2015). Age-related changes in hematologic and serum biochemical variables in dogs aged 16-60 days. Veterinary Clinical Pathology, 44, 47-57.

Schoeman, J.P., Goddard, A. \& Leisewitz, A.L. (2013). Biomarkers in canine parvovirus enteritis. New Zealand Veterinary Journal, 61, 217-222.

Shibutani, M., Maeda, K., Nagahara, H., Ohtani, H., Iseki, Y., Ikeya, T., Sugano, K. \& Hirakawa, K. (2015). The pretreatment albumin to globulin ratio predicts chemotherapeutic outcomes in patients with unresectable metastatic colorectal cancer. BMC Cancer, 15, 347.

Sugimoto, K., Komiyama, H., Kojima, Y., Goto, M., Tomiki, Y. \& Sakamoto, K. (2012). Glasgow prognostic score as a prognostic factor in patients undergoing curative surgery for colorectal cancer. Digestive Surgery, 29, 503-509.

Tothova, C., Nagy, O. \& Kovac, G. (2016). Serum proteins and their diagnostic utility in veterinary medicine: A review. Veterinární Medicína, 61, 475-496.

Van den Broek, A.H.M. (1990). Serum protein electrophoresis in canine parvovirus enteritis. British Veterinary Journal, 146, 255-259.

Weaver, D.M., Tyler, J.W., Van Metre, D.C., Hostetler, D.E. \& Barrington, G.M. (2000). Passive transfer of colostral immunoglobulins in calves. Journal of Veterinary Internal Medicine, 14, 569577.

Yilmaz, Z. \& Senturk, S. (2007). Characterization of lipid profiles in dogs with parvoviral enteritis. Journal of Small Animal Practice, 48, 643-650.

Zhou, T., He, X., Fang, W., Zhan, J., Hong, S., Qin, T., Ma, Y., Sheng, J., Zhou, N., Zhao, Y., Huang, Y. \& Zhang, L. (2016). Pretreatment albumin/globulin ratio predicts the prognosis for small-cell lung cancer. Medicine (Baltimore), 95, e3097. 